\title{
CIRCULATION FLOW OF ENTEROPATHOGENIC BACTERIA IN INSTITUTIONALIZED CHILDREN. I. AN EPIDEMIOLOGIC STUDY
}

\author{
MARIA DIANA LACERDA \& ERNESTO HOFER
}

Instituto Oswaldo Cruz, Departamento de Bacteriologia, Caixa Postal 926, 20001 Rio de Janeiro, RJ, Brasil

The circulation flow and maintenance of enteropathogenic bacteria were studied from May 1982 to April 1983 in a population of institutionalized children and adult staff contacts in the city of Rio de Janeiro, Brazil. Subjects were assigned to three groups: A and B, included, respectively, 105 and 46 children with diarrhea who were admitted in the institution in different periods, and group $C$ with 82 adult contacts. Faecal cultures were positive in $35.2 \%, 39.1 \%$ and $19.7 \%$ of subjects of groups $A, B$, and $C$, respectively. It suggests that the transmission was probably fostered by the environment because of as high as $30 \%$ of faecal contamination was found in environmental samples. Higher rate of isolation and elevated antibodies levels pointed out that Escherichia coli (EPEC) was the prevalent agent. Shigella predominated in the serological tests. These findings suggest that the institution itself may play an important role in the epidemiology and transmission of enteric infections in the community.

Key words: circulation flow - enteropathogenic bacteria - children infection - epidemiological data

Several studies have demonstrated the role of day-care centers, nursery schools, asylums and similar institutions in the maintenance and spreading of diarrhoeal infections. Most of these investigations were retrospective studies carried out after epidemic outbreaks in order to determine the occurrence of specific aetiological agents, Shigella in particular (Weissman et al., 1974, 1975; Rosenberg et al., 1976; Koopman, 1978).

More recente studies have emphasized the role of multiple pathogens at these centers using a longitudinal approach (Pickering et al., 1981; Ekanem et al., 1983).

In Brazil, most of the studies were conducted focusing hospital environments in attempt to correlate the level of environmental contamination with agents isolated from diarrhoeal subjects (Pessôa et al., 1980); aetiology with clinical characterization (Osmo et al., 1983; Queiroz et al., 1985) and/or with distribution of infectious agents at the community level (Giugliano \& Giugliano, 1985).

To our knowledge, this is the first study performed in Brazil relating the intensity of the enteropathogenic bacteria circulation flow among institutionalized children with the level

Received April 15, 1988.

Accepted August 26, 1988. of environmental contamination and the immune response to the infectious agents.

\section{MATERIALS AND METHODS}

Study design and population - A sectional study during the period of May 1982 to April 1983 was carried out in an official institution receiving and screening abandoned children (RSC-II) aged 0 to 5 years, located in the city of Rio de Janeiro. The characteristics of the Center and the populational groups studied are shown in Table $I$.

Laboratory tests - The subjects were screened daily, except on week ends and holidays, by one of the physicians for clinical indications of diarrhoea defined as the occurrence of three ou more loose or watery stools in one day.

Faecal and environmental samples were cultured for identification of Salmonella, Shigella, enteropathogenic Escherichia coli (EPEC, ETEC and EIEC), and Campylobacter by laboratory methods detailed elsewhere (Lacerda et al., 1988). Environmental samples were collected in three different occasions by swabs humidified with sterile distilled water in the dormitories, milk dispensaries and kitchen from surfaces, tools and toys. It was assumed that the presence of Shigella, Salmonella or faecal coliforms reflected faecal contamination. 
TABLE I

Characteristics of the RSC-II and the groups studied, 1982-1983

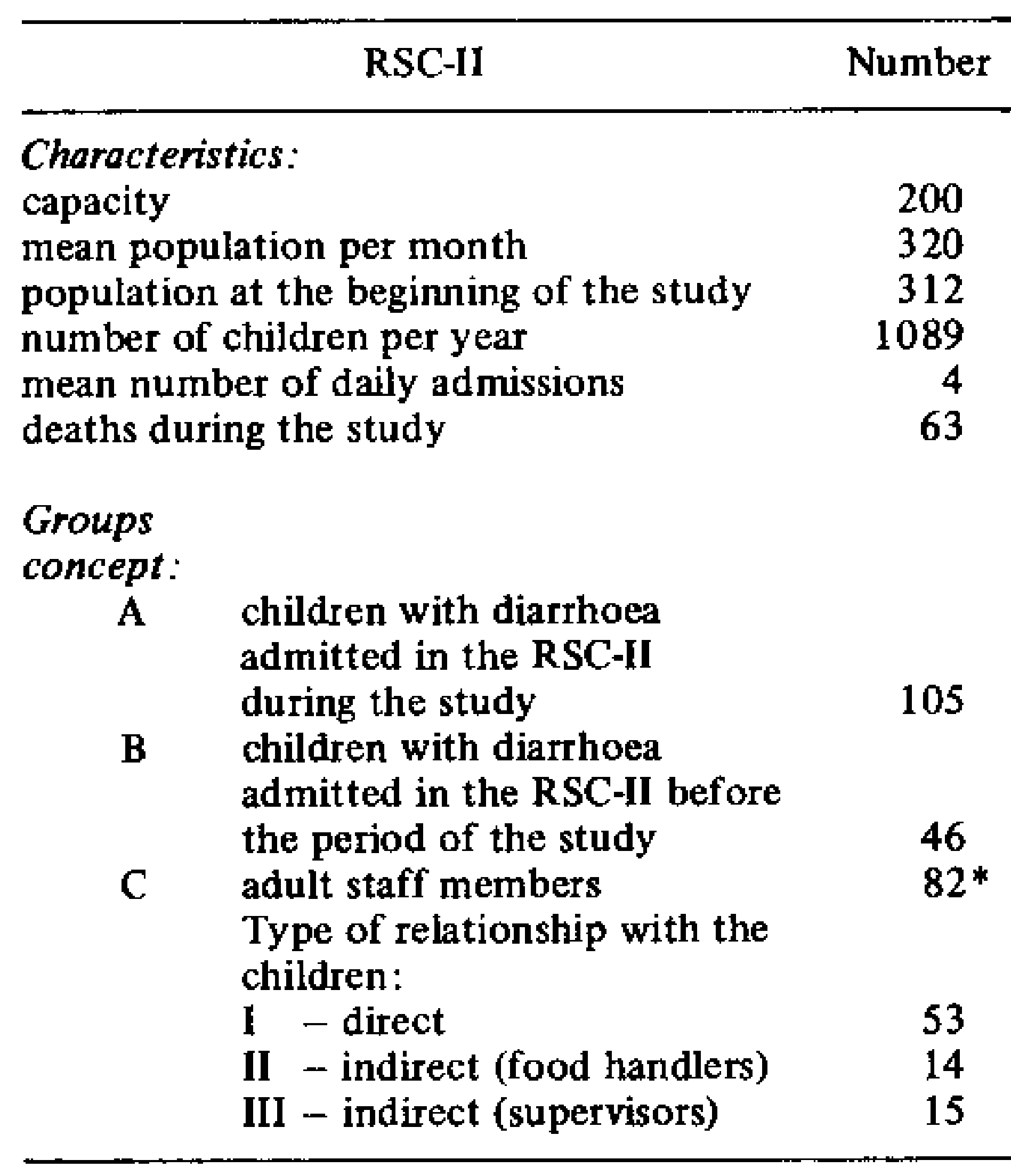

* This includes 6 subjects with enteric infection.

A total of 155 paired serum samples were analyzed for antibodies to the enteropathogenic agents EPEC, ETEC, Salmonella and Shigella by the passive hemagglutination technique described by Neter et al. (1956) and further modified by Cáceres \& Mata, 1970 .

Statistical analysis - Data were analyzed statistically by the non-parametric $\chi^{2}$ and Mann-Whitney tests with the level of significance set at 0.05 . When the expected value was less than 5, Fisher's test of exact probability was used.

\section{RESULTS}

Faecal culture and environmental contamination - Enteropathogenic bacteria were detected in 76 individuals (32.6\%), as shown in Table II.

Table III shows that there was no significant difference among positive faecal cultures by age range (groups $A$ and $B$ ) and by level of relation. ship in group $C$. However, it should be pointed out that the positivity of faecal cultures was higher in group B $(39.1 \%)$ than in group A (32.2\%).

\section{TABLE II}

Frequency of enteropathogenic bacteria isolated from individuals investigated at the RSC-II from 1982 to 1983

\begin{tabular}{lcccrc}
\hline & \multicolumn{3}{c}{ Groups } & Total & $\%$ \\
\cline { 2 - 4 } & A & B & C & & \\
\hline Positive & 37 & 18 & 21 & 76 & 32.6 \\
Negative & 68 & 28 & 61 & 157 & 67.4 \\
\hline Total & 105 & 46 & 82 & 233 & 100.0 \\
\hline
\end{tabular}

Enteropathogenic Escherichia coli (EPEC) was the most frequently detected agent in all groups screened, followed by enterotoxic Escherichia coli (ETEC) among the children, and by Campylobacter among the adults (Table IV).

The average rate of faecal contamination in the environment was as high as $30 \%$, ranging from 18 to $33 \%$ (Table V). Contamination with faecal coliforms was highest in the dormitories (56) and lowest in the milk dispensary (8), which was the only area in which the first collection showed no contamination. Faecal coliforms were rarely detected on toilet seats or chairs.

Serum reactivity - Table VI shows the distribution of the serum titres for each of the four antigens tested (EPEC, ETEC, Shigella and Salmonella) as compared with bacteria isolation from faecal cultures. Thus, titres were significantly more elevated $(p<0,05)$ among individuals with positive faecal cultures in relation to negative subjects, specially for Shigella and EPEC.

\section{DISCUSSION}

The large urban centers located in developing regions, such as the city of Rio de Janeiro, represent a real epidemiologic mosaic, where different population groups with different pathologies and specific characteristics converge and overlap.

The exposure of these groups to risks of different types and magnitudes caused by factors of the biological, physical, sociocultural and economic environments, models their life conditions and their health profiles (OPAS, 
TABLE III

Faecal culture positivity among group A and B children by age range and among adults as a function of level of relationship with the children

(RCS-II, 1982-1983)

\begin{tabular}{|c|c|c|c|c|c|c|c|}
\hline \multirow{3}{*}{ Age range } & \multicolumn{7}{|c|}{ Groups } \\
\hline & \multicolumn{2}{|l|}{ A } & \multicolumn{2}{|l|}{ B } & \multicolumn{3}{|c|}{$\mathrm{C}$} \\
\hline & $\begin{array}{l}\text { Positive/ } \\
\text { examined }\end{array}$ & $\%$ & $\begin{array}{l}\text { Positive/ } \\
\text { examined }\end{array}$ & $\%$ & $\begin{array}{l}\text { Relationship } \\
\text { (level) }\end{array}$ & $\begin{array}{l}\text { Positive/ } \\
\text { examined }\end{array}$ & $\%$ \\
\hline $\begin{array}{l}<1 \\
1-3 \\
3-5\end{array}$ & $\begin{array}{l}12 / 35 \\
15 / 41 \\
10 / 29\end{array}$ & $\begin{array}{l}34.3 \\
36.6 \\
34.5\end{array}$ & $\begin{array}{c}5 / 11 \\
10 / 26 \\
3 / 9\end{array}$ & $\begin{array}{l}45.5 \\
38.5 \\
33.3\end{array}$ & $\begin{array}{c}\text { I } \\
\text { II } \\
\text { III }\end{array}$ & $\begin{array}{r}10 / 53 \\
7 / 14 \\
4 / 15\end{array}$ & $\begin{array}{l}18.9 \\
50.0 \\
26.7\end{array}$ \\
\hline Total & $37 / 105$ & 35.2 & $18 / 46$ & 39.1 & Total & $21 / 82$ & $25.6^{*}$ \\
\hline
\end{tabular}

* This includes $19.6 \%$ of healthy carriers.

TABLE IV

Frequency of enteropathogenic bacteria isolated from group A, B and C subjects (RCS-II, 1982-1983)

\begin{tabular}{|c|c|c|c|c|c|c|c|c|}
\hline \multirow{3}{*}{ Bacteria } & \multicolumn{8}{|c|}{ Groups } \\
\hline & \multicolumn{2}{|r|}{ A } & \multicolumn{2}{|r|}{ B } & \multicolumn{4}{|c|}{$\mathrm{C}$} \\
\hline & No. & $\begin{array}{c}\% \text { of total } \\
\text { no. of } \\
\text { cultures } \\
(105)\end{array}$ & No. & $\begin{array}{l}\% \text { of total } \\
\text { no. of } \\
\text { cultures } \\
(46)\end{array}$ & No. & $\begin{array}{l}\text { With diarrhoea } \\
\% \text { of total no. } \\
\text { of cultures } \\
(6)\end{array}$ & No. & $\begin{array}{c}\text { Without diarrhoea } \\
\% \text { of total no. } \\
\text { of cultures } \\
(76)\end{array}$ \\
\hline $\begin{array}{l}\text { EPEC } \\
\text { ETEC } \\
\text { Salmonella } \\
\text { Shigella } \\
\text { Campylobacter } \\
\text { EIEC }\end{array}$ & $\begin{array}{r}12 \\
9 \\
5 \\
8 \\
4 \\
0\end{array}$ & $\begin{array}{r}11.4 \\
8.6 \\
4.8 \\
7.6 \\
3.8 \\
0.0\end{array}$ & $\begin{array}{r}10 \\
6 \\
2 \\
3 \\
0 \\
0\end{array}$ & $\begin{array}{r}21.7 \\
13.0 \\
4.3 \\
6.5 \\
0.0 \\
0.0\end{array}$ & $\begin{array}{l}3 \\
0 \\
1 \\
1 \\
2 \\
0\end{array}$ & $\begin{array}{r}50.0 \\
0.0 \\
16.7 \\
16.7 \\
33.3 \\
0.0\end{array}$ & $\begin{array}{l}7 \\
3 \\
0 \\
0 \\
6 \\
1\end{array}$ & $\begin{array}{l}9.2 \\
3.9 \\
0.0 \\
0.0 \\
7.9 \\
1.3\end{array}$ \\
\hline Total & 38 & - & 21 & - & 7 & - & 17 & - \\
\hline
\end{tabular}

$\mathrm{EPEC}=$ enteropathogenic Escherichia coli $; \mathrm{ETEC}=$ enterotoxic Escherichia coli $;$ EIEC $=$ invasive Escherichia coli.

TABLE V

Frequency of faecal coliform organisms isolated from material collected from various environmental sites at the RSC-II from 1982 to 1983

\begin{tabular}{|c|c|c|c|c|c|c|}
\hline \multirow{2}{*}{ Collections } & \multirow{2}{*}{$\begin{array}{l}\text { No. of samples } \\
\text { tested }\end{array}$} & \multicolumn{3}{|c|}{ No. of faecal coliform organisms } & \multirow{2}{*}{ Total } & \multirow[b]{2}{*}{$\%$} \\
\hline & & Dormitory & $\begin{array}{c}\text { Milk } \\
\text { dispensary }\end{array}$ & Kitchen & & \\
\hline $\begin{array}{l}1 \mathrm{st} \\
2 \mathrm{nd} \\
3 \mathrm{rd}\end{array}$ & $\begin{array}{l}65 \\
98 \\
87\end{array}$ & $\begin{array}{r}7 \\
27 \\
22\end{array}$ & $\begin{array}{l}0 \\
4 \\
4\end{array}$ & $\begin{array}{l}5 \\
3 \\
3\end{array}$ & $\begin{array}{l}12 \\
34 \\
29\end{array}$ & $\begin{array}{l}18.5 \\
34.5 \\
33.3\end{array}$ \\
\hline Total & 250 & 56 & 8 & 11 & 75 & 30.0 \\
\hline
\end{tabular}


TABLE VI

Comparison between the isolation of enterobacteria from faecal cultures and the highest antibody titre (RCS - II, 1982-1983)

\begin{tabular}{|c|c|c|c|c|c|c|c|c|}
\hline \multirow{3}{*}{$\begin{array}{l}\text { Antibody } \\
\text { titre }\end{array}$} & \multirow{2}{*}{\multicolumn{2}{|c|}{ EPEC }} & \multicolumn{4}{|c|}{ Patients with isolates to } & \multirow{2}{*}{\multicolumn{2}{|c|}{ Shigella }} \\
\hline & & & \multicolumn{2}{|c|}{ ETEC } & \multicolumn{2}{|c|}{ Salmonella } & & \\
\hline & no. & $\%$ & no. & $\%$ & no. & $\%$ & no. & $\%$ \\
\hline$\leqslant 1: 20$ & 2 & 9,5 & 2 & 25,0 & 0 & 0,0 & 0 & 0,0 \\
\hline $1: 40$ & 3 & 14,3 & 4 & 50,0 & 2 & 33,3 & 1 & 11,1 \\
\hline $1: 80$ & 8 & 38,0 & 0 & 0,0 & 1 & 16,7 & 2 & 22,2 \\
\hline $1: 160$ & 3 & 14,3 & 0 & 0,0 & 1 & 16,7 & 3 & 33,3 \\
\hline $1: 320$ & 3 & 14,3 & 2 & 25,0 & 1 & 16,7 & 1 & 11,1 \\
\hline$\geqslant 1: 640$ & 2 & 9,6 & 0 & 0,0 & 1 & 16,7 & 2 & 22,2 \\
\hline Total & 21 & 100,0 & 8 & 100,0 & 6 & 100,0 & 9 & 100,0 \\
\hline
\end{tabular}

One - tailed Mann-Whitney test.

1984). In this respect, the vulnerability of the child population to diarrhoeic disease, especially in institutionalized groups, has been the subject of epidemiological studies, which show the contributing factors for the wide transmission of enteric organisms in such populations (Weissman et al., 1975; Pickering et al., 1981; Sullivan et al., 1984).

Our results are in agreement with other reports (Weissman et al., 1975; Pickering et al., 1981; Sullivan et al., 1984) and demonstrating that the high circulation of enteric pathogens in the ecosystem studied may be due to the following aspects: (1) inadequate institutional structure; (2) non-trained staff in terms of providing care of the children; and (3) kind of population involved (abandoned and frequently carriers of other infectious diseases). Thus, the cluster and intensive children turnover in the Center provide a situation, in which, person-toperson contact is accentuated and the potential spread of many infectious diseases is increased.

The positive faecal cultures obtained from patients with diarhoea in groups $\mathrm{A}$ and $\mathrm{B}$ reflect the relevance of enterobacteria in diarrhoeal processes and the intense circulation of some types at the institutional level, as also reported in other national surveys (Trabulsi et al., 1982; Osmo et al., 1983; Giugliano \& Giugliano, 1985). Furthermore, this higher incidence among children probably results from greater exposure to enteropathogenic bacteria than from host susceptibility (Pickering et al., 1981). The present results may corroborate this hipothesis by the fact that there was no signifi- cant correlation between age and enterobacteria isolation or between age and antibody response to the pathogens.

Also, an association between enterobacteria elimination and longer time of dwelling in the Center would be expected. However, despite of the occurrence of slightly higher rates in group B (with longer exposure), there was no significant difference between groups $\mathbf{A}$ and $\mathbf{B}$, suggesting close homogeneity of the two groups or perhaps the interaction of other elements which caused the risks of infection to be uniformly distributed among the two groups.

The detection of EPEC both among adult carriers $(9.2 \%)$ as well as in diarrhoeal individuals $(50 \%)$ is of great importance, since adults are considered as immune to EPEC agression (Neter et al., 1956). This finding could be interpreted as the result of intense exposure of the adult group to circulating bacteria. The carrier status could also be partially attributed to the precarious health and sanitation conditions and to the low educational level of the subjects (Figueroa et al., 1983).

Serologic reactivity was higher for Shigella and EPEC than for other organisms, with aproximately 90 and $80 \%$ of individuals, respectively, with positive faecal cultures showing titres $1 / 80$. However, it should be pointed out that elevated titres (40 to $50 \%$ ) were found for patients with negative faecal cultures, especially for the two agents above. This aspect confirms the limitation of laboratory methods taken separately and the need to 
complement bacteriological procedures with serological tests. Particularly concerning to Shigella, its isolation requires specimen collection in the peak of the process on a serial basis (Cáceres \& Mata, 1970). On the other hand, passive hemagglutination test has proved to be highly specific for Shigella (Cáceres \& Mata, 1970; 1974), permiting the diagnosis of twice as many cases as diagnosed by faecal culture.

Thus, on the basis of bacteriologic and serologic evaluations, it may be inferred that EPEC and Shigella were endemic in the ecosystem studied and possibly had already colonized it, whereas the flow of the remaining bacteria was transitory or occasional. It should be emphasized, however, that the number of infecting sources was expressed only by the percentage of positive faecal cultures (group A, $35.2 \% ; \mathrm{B}, 39.1 \%$; $\mathrm{C}, 19.7 \%$ ), and that it was not possible to analyse all the diarrhoea cases or to estimate the frequency of carriers among children after the enteric episodes.

The participation of transmission pathways other than person-to-person contact should also be considered as a fundamental aspect in the circulation and maintenance of the agents, in view of the fact that $30 \%$ of the environmental samples showed faecal contamination. This rate was higher than those obtained by Pessôa et al. (1980) in university hospital nurseries (4.9\%) and in public health hospitals $(25.2 \%)$, and lower than those related in outbreaks -32 to $36 \%$ (Ekanem et al., 1983).

According to Koopman et al. (1978), a system of enteric transmission is formed by the successive chain of faecal contacts which is established among susceptible individuals and by the factors that favor such contacts. On the basis of this concept, it is proposed that the children and adults studied in the present investigation may be interacting with, and be exposed to a transmission chain whose renewable and uninterrupted links may be determined by the peculiar characteristics of the Center, by the conditions of the population and by the biological characteristics of the agents. Consequently, starting from a sick child, the enterobacteria can easily spread throughout the environment, so that this Screening Center represents a high-risk ecosystem with the potential ability to transmit enteric infections to the community.

\section{ACKNOWLEDGEMENTS}

The authors are grateful to Prof. Walter Leser for his helpful assistance in analysis of the results, and to Mrs. Joana D'Arc Cardoso Pontes for technical assistance. We are also indebted to the Centro de Recepção e Triagem Marieta de Chagas Freitas, which made this survey possible.

\section{RESUMO}

Circulação de enterobactérias patogênicas em crianças institucionalizadas. I - Estudo epidemiológico - Durante o período de um ano (maio de 1982 - abril de 1983) avaliou-se a circulaçāo e manutençāo de bactérias enteropatogênicas, em população de menor institucionalizada e funcionários adultos contactantes, na cidade do Rio de Janeiro, Brasil. Foram constituídos três grupos: A e B incluíram, respectivamente, 104 e 46 crianças, portadoras de quadro diarréico, diferenciando-se pelo período de ingresso na instituição, anterior (B) e durante (A) o período do estudo; o grupo $C$ era composto de 82 adultos contactantes. Fontes de infecção parcialmente expressas pela positividade de coproculturas: $35,2 \%$ no grupo $\mathbf{A}$, $39,1 \%$ no $B$ e $19,7 \%$ nos adultos sadios, sugerem a potencialidade de outras vias de transmissão representadas pelo ambiente com $30 \%$ de contaminação fecal. Maior taxa de isolamento combinada a elevados títulos de anticorpos indicaram Escherichia coli (EPEC) como o agente prevalente, enquanto que na hemaglutinação passiva, Shigella predominou. Admite-se que a instituição deve desempenhar um papel importante na epidemiologia e transmissão de infecçōes entéricas para a comunidade.

Palavras-chave: epidemiologia - gastroenterites (infantil) - enterobactéria - transmissão

\section{REFERENCES}

CACERES, A. \& MATA, L. J., 1970. Hemaglutination indirecta para la investigación de anticuerpos a enterobacteriáceas. Rev. Lat. Amer. Microbiol, 12 . 137.144 .

CÁCERES, A. \& MATA, L. J., 1974. Serological response of patients with Shiga dysenteriae. J. Infect, Dis., 129:439-443.

EKANEM, E. E.; DUPONT, H. L. ; PICKERING, L. K.; SELWIN, B. J. \& HAWKINS, C. M., 1983. Transmission dynamics of enteric bacteria in day care centers. Am. J. Epidemiol., 118:562-572.

FIGUEIROA, G.; TRONCOSO, M.; ARAYA, M.; ESPINOZA, J. \& BRUNSER, O., 1983. Enteropathogen carriage by health individuals living in an area with poor sanitation. J. Hyg., 91:499-507. 
GIUGLIANO, L. G. \& GIUGLIANO, R., 1985. Etiologia das diarréias agudas em Manaus: observações ambulatoriais e na comunidade. Rev. Microbiol., 16: 234-239.

KOOPMAN, J. S., 1978. Diarrhea and school toilet hygiene in Cali, Colombia. Am. J. Epidemiol, 107: 412-420.

KOOPMAN, J. S.; GUZMAN, N.; HENAO, O. \& BERGONZOLI, G., 1978. Vigilância de las enfermidades diarréicas: Programa em Cali, Colombia. Bol. Sanit. Panam., 35: 307-314.

LACERDA, M. D. ; PONTES, J. D. C. \& HOFER, E., 1988. Circulaçāo de bactéria enteropatogênica em crianças institucionalizadas. II. Estudo bacteriológico. Rev. Microbiol., 19: 135-40.

NETER, E.; WESTPHAL, O.; LUDERITZ, O. \& GORZYNSKI, E. A., 1956. The bacterial hemagglutination test for the demonstration of antibodies to enterobacteriaceae. Ann. New York Acad. Sci., 66: 141-156.

OPAS - BOLETIN EPIDEMIOLOGICO, 1984. 5: $1-16$.

OSMO, A. A.; DE ARAUJO, M. D.; BARISON, E.; GILIO, A. E.; BERNARE, A. L. B.; CARNEIRO, R. G.; DA COSTA, M. T.; MANISSADJAN, A. \& MANIZUKA, E. E., 1983. Estudo etiológico de 252 casos de diarréia aguda internados no Hospital Universitário da Universidade de São Paulo. Rev. Pediat., 5: 175-183.

PESSÓA, G. V. A.; SUGUIMORI, R. T.; IRINO, K.; RASKIN, M. \& CALZADA, C. T., 1980. Isolamento de enterobactérias patogênicas em berçários do município de São Paulo. Rev. Inst. Adolfo Lutz, 40: $107-127$.

PICKERING, L. K.; EVANS, D. G.; DUPONT, H. L.; VOLLET, J. J. \& EVANS, D. J., 1981. Diarthea caused by Shigella, Rotavirus, and Giardia in Day Care Centers: Prospective study. J. Pediat., 99: 51.56.

QUEIROZ, D. M.; MENDES, E. N.; CISALPINO, E. O.; PERES, J. N. \& PENNA, F. J., 1985. Frequiência de Escherichia coli enteropatogênica em crianças com diarréia aguda e em controles, em Belo Horizonte. Rev. Microbiol, 16:95-100.

ROSENBERG, M. L.; WEISSMAN, J. B.; GANGAROSA, E. J.; RELLER, L. B. \& BREASLEY, R. P., 1976. Shigellosis in the United States: ten year review of nation wide surveillance, 19641973. Am. J. Epidemiol, 104: 543-551.

SULLIVAN, P.; WOODWARD, W. E.; PICKERING, L. K. \& DUPONT, H. L. 1984. Longitudinal study of occurrence of diarrheal disease in day care centers. Am. J. Pub. Hlth., 74:987-991.

TRABULSI, L. R.; TOLEDO, M. R. \& MURAHOVSCHI, J., 1982. Epidemiology of infantile bacterial diarthoeal diseases in Brazil. In: International Symposium on Bacterial Diarrhoeal Diseases. Osaka, Japan.

WEISSMAN, J. B.; GANGAROSA, F. J.; SCHMERLER, A.; MARIER, R. L.; LEWIS, J. N., 1975. Shigellosis in day-care centers. Lancet, I: 88-90.

WEISSMAN, J. B.; SCHMERLER, A.; WEILER, P., 1974. The role of pre-school children and day care-centers in the spread of shigellosis in urban communities. J. Pediat., 84: 797-802. 